\title{
Phenotypic diversity in siblings with partial androgen insensitivity syndrome
}

\author{
B A J Evans, I A Hughes, C L Bevan, M N Patterson, J W Gregory
}

\begin{abstract}
The androgen insensitivity syndrome is a heterogeneous disorder with a wide spectrum of phenotypic abnormalities, ranging from complete female to ambiguous forms that more closely resemble males. The primary abnormality is a defective androgen receptor protein due to a mutation of the androgen receptor gene. This prevents normal androgen action and thus leads to impaired virilisation. A point mutation of the androgen receptor gene affecting two siblings with partial androgen insensitivity syndrome is described. One had cliteromegaly and labial fusion and was raised as a girl, whereas the other sibling had micropenis and penoscrotal hypospadias and was raised as a boy. Both were shown to have the arginine 840 to cysteine mutation. The phenotypic variation in this family is thus dependent on factors other than abnormalities of the androgen receptor gene alone. (Arch Dis Child 1997;76:529-531)
\end{abstract}

Keywords: androgen receptor mutations; androgen insensitivity syndrome; phenotypic diversity

Mutations of the androgen receptor gene in subjects with a 46,XY karyotype give rise to the androgen insensitivity syndrome (AIS). The syndrome is a heterogeneous disorder with a wide spectrum of phenotypic abnormalities ranging from complete female to ambiguous forms that more closely resemble males. The primary abnormality is a defective androgen receptor protein which prevents normal androgen action and thus leads to impaired virilisation. $^{1-3}$

The androgen receptor protein is encoded

Department of Child Health, University of Wales College of Medicine, Heath Park, Cardiff CF4 4XN

B A J Evans

JW Gregory

Department of Paediatrics, University of Cambridge, Addenbrooke's Hospital, Cambridge

I A Hughes

C L Bevan

M N Patterson

Correspondence to: Dr Evans.

Accepted 5 March 1997 base mutations that introduce premature termination codons, amino acid changes, or aberrant messenger RNA splicing. ${ }^{6}$
Four sites in the steroid binding domain, arginine residues 774,840 , and 855 , and valine 866, appear to have a particularly high frequency of mutation and together account for about one quarter of the missense mutations reported to date. ${ }^{36}$ Arginine 840 is reported to be the site of substitution by either cysteine or histidine in multiple patients (three and nine patients, respectively). These substitutions are both associated with a variety of phenotypes within the partial form of AIS, highlighting the complexity of the genotypephenotype relation in androgen insensitivity. ${ }^{3}$ Indeed, even within a few families with partial AIS considerable phenotypic variability has been reported, ${ }^{78}$ although most of these reports were before mutational analyses of the androgen receptor gene were possible. The molecular basis of this phenotypic variation has been investigated in only a few families ${ }^{9}$ and is still not understood.

We describe a point mutation of the androgen receptor gene affecting two siblings with the partial form of the AIS in a completely different manner. One had cliteromegaly and labial fusion and was raised as a girl, whereas the other sibling had micropenis and penoscrotal hypospadias and was raised as a boy. Both were shown to have the arginine 840 to cysteine mutation.

Subjects and methods

The family pedigree is shown in fig 1 . The index case (II.1) was born at 32 weeks' gestation by caesarean section weighing $1980 \mathrm{~g}$ and was noted at birth to have ambiguous genitalia. The phallus measured $1.5 \mathrm{~cm}$, there was a urogenital sinus, a $1 \mathrm{~cm}$ blind ending vagina, and both gonads were palpable in the labioscrotal folds. The karyotype was $46, \mathrm{XY}$ and there was a significant testosterone response $(7.5$ to $>20 \mathrm{nmol} / \mathrm{l})$ to human chorionic gonadotrophin stimulation undertaken within one month of birth. The infant was assigned a female gender and at 21 months underwent vulvoplasty, bilateral orchidectomy, and herniotomy. On examination at the age of 9 years she had normal external female genitalia.

A younger sibling (II.2) was born two years later and was noted at birth to have a slightly shortened penis, penoscrotal hypospadias with chordee, and a bifid scrotum with both testes palpable. Cystourethroscopy was normal and the karyotype was $46, \mathrm{XY}$. As he was substantially more virilised than his sister, he was raised as a boy and underwent a Duckett's hypospadias repair aged 14 months. At 7 years of age his phallus measured $2.5 \mathrm{~cm}$ and his 

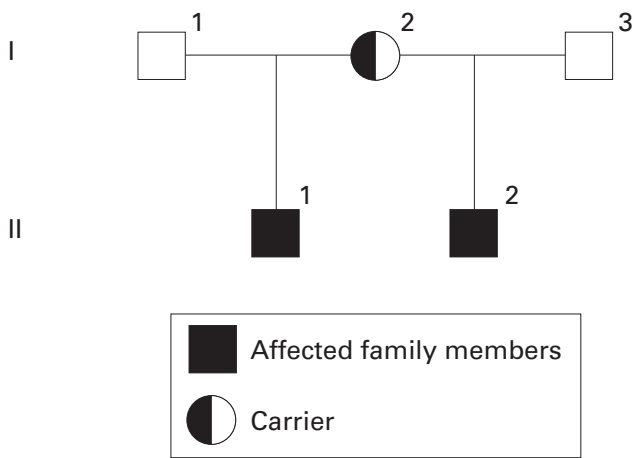

Figure 1 Pedigree of family with partial androgen insensitivity and variable phenotype.

scrotum was well developed, although the testes were palpable in the inguinal canal.

TISSUE CULTURE AND ANDROGEN BINDING ASSAY A fibroblast cell line was established from a genital skin biopsy sample obtained from II.2 at the time of his operation. Normal control cell lines were established from circumcision specimens. Androgen binding was measured using whole cell binding assays as previously described. ${ }^{10}$

POLYMERASE CHAIN REACTION SINGLE STRAND CONFORMATION POLYMORPHISM ANALYSIS AND SEQUENCING OF THE ANDROGEN RECEPTOR GENE Genomic DNA was prepared from whole blood from I.2, I.3, II.1, and II.2 using standard methods. ${ }^{11}$ The androgen receptor gene was screened for mutations using polymerase chain reaction single strand conformation polymorphism (PCR-SSCP) techniques as described elsewhere. ${ }^{12}{ }^{13}$ Sequencing reactions were also carried out as previously described ${ }^{13}$ using the fmol DNA sequencing system (Promega).

\section{Results}

The maximum binding capacity and apparent dissociation constant $\left(\mathrm{K}_{\mathrm{d}}\right)$ for the androgen receptor in genital skin fibroblasts from II.2 were $749 \times 10^{-18} \mathrm{~mol} / \mu \mathrm{g}$ DNA and $2.9 \times 10^{-10}$ $\mathrm{mol} / 1$ (normal range $814+/-186$ and $0.91+/-$ 0.26 , respectively, $n=14$ ). This $K_{d}$ is $3.1-$ fold higher than that in normal subjects. Androgen binding at $40^{\circ} \mathrm{C}$ decreased to $55 \%$ of the value obtained when the assay was performed at $37^{\circ} \mathrm{C}$ (normal range $+/-16 \%$ ). The altered binding affinity and thermolability indicate that this cell line expresses an androgen recep- tor which is qualitatively abnormal. SSCP screening of exon $G$ showed a shift in the mobility of denatured PCR segments from II.1 and II.2 when run on a non-denaturing gel (results not shown). Direct sequencing of exon $\mathrm{G}$ in subjects II. 1 and II.2 confirmed the presence of a point mutation (guanine to adenine) causing a change from arginine to cysteine at amino acid 840 (fig 2). Their mother, I.2, was shown to be a carrier for this point mutation (fig 2).

\section{Discussion}

This study reports a single amino acid substitution (arginine to cysteine at position 840 ) in the steroid binding domain of the androgen receptor gene in two patients with partial AIS. This particular codon is reported as one 'hotspot' of mutations based on the current database of the androgen receptor gene mutations. ${ }^{6}$ Table 1 summarises the reported mutations of arginine 840 in relation to the affected phenotype of the index case where sufficient clinical details were available. There is no consistency in the sex of rearing between affected families. Within affected families, however, siblings have generally been similarly affected and raised as the same sex. ${ }^{14-16}$ There is one report of a Japanese case where the index patient was female, but other family members who had abnormal genitalia were raised as boys. ${ }^{17}$

Our family is unique in showing such a profound difference in the degree of virilisation so that the decision about the sex of rearing was clear from the outset in each instance. Such intrafamilial variance in the phenotypic expression of an identical single gene mutation emphasises the need to approach prenatal counselling of partial AIS with caution. ${ }^{18}$ Predicting outcome is more certain with complete AIS, where within affected families there is no partial form of AIS and hence the sex of rearing would always be female. An arginine 855 histidine mutation was reported to result in complete AIS in one family and a partial AIS phenotype in another unrelated family, however. ${ }^{15}$ The androgen receptor is a member of a large family of nuclear transcription factors which are usually activated in the presence of ligand binding to specific pockets in the formation of the tertiary protein structure. ${ }^{19}$ Other examples of dysfunctional transcription factors due to a single mutation, but associated with a spectrum of clinical expression, include

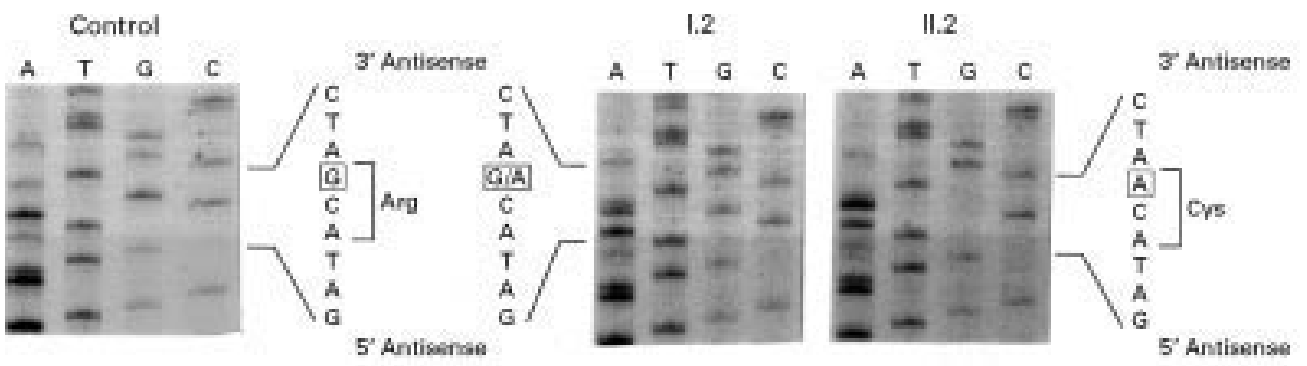

Figure 2 Sequencing of exon G in subjects I.2 and II.2. The sequencing abnormality seen in II. 2 was also detected in II. 1 (results not shown). The altered nucleotide is boxed. The resultant change in amino acids is also shown. Arg = arginine; Cys = cysteine. 
Table 1 Phenotype at birth and sex of rearing of index case from families reported to have an androgen receptor gene mutation which changes amino acid 840 of the androgen receptor

\begin{tabular}{llll}
\hline Change at amino acid 840 & Phenotype & Sex of rearing & Reference \\
\hline Arginine to cysteine & Cryptochidism/hypospadias & $\mathrm{M}$ & 14 \\
& Reifenstein $^{\star}$ & $\mathrm{M}$ & 15 \\
& Reifenstein & $\mathrm{M}$ & 15 \\
Arginine to histidine & Ambiguous genitalia & $\mathrm{F}$ & 16 , this paper \\
& Ambiguous genitalia & $\mathrm{F}$ & 17 \\
& Ambiguous genitalia & $\mathrm{F}$ & 14 \\
& Ambiguous genitalia & $\mathrm{F}$ & 14 \\
& Ambiguous genitalia & $\mathrm{F}$ & 15 \\
& Ambiguous genitalia & $\mathrm{M}$ & 15,18 \\
& Ambiguous genitalia & $\mathrm{F}$ & 19 \\
& Ambiguous genitalia & $\mathrm{F}$ & 20 \\
& Ambiguous genitalia & $\mathrm{M}$ & 21
\end{tabular}

^ Perineoscrotal hypospadias and gynaecomastia.

generalised versus pituitary resistance in thyroid hormone resistance syndromes ${ }^{20}$ and variable sex reversal in the campomelic dysplasia syndrome. ${ }^{21}$ We have also reported the complete absence of phenotypic expression in a sibling who had the same activating luteinising hormone receptor mutation as his brother with precocious puberty. ${ }^{22}$ Furthermore, other mutations of the same luteinising hormone receptor gene can be inactivating, resulting in marked variability in undervirilisation of affected boys depending on the degree of Leydig cell hypoplasia. ${ }^{23}$ Where the phenotype does not match the genotype has been the subject of a publication of a symposium on this topic as it affects a wide spectrum of clinical disorders. ${ }^{24}$

The arginine 840 cysteine mutation is the proved cause of androgen insensitivity in these two siblings, as reported in a separate study. ${ }^{25}$ The binding abnormality was confirmed on recreating and expressing the mutation in mammalian cells. Furthermore, the activation of a reporter gene by the mutated androgen receptor construct was markedly deficient in the presence of androgen, apart from a suboptimum response only when supraphysiological concentrations of androgen were tested. This observation in vitro does not readily explain the intersibling variance in the severity of undervirilisation. High local concentrations of active androgens are required during critical periods of fetal development for normal sex differentiation. We can postulate whether androgen production was sufficiently variable at this period to result in such different phenotypes. Evidence to suggest antiandrogenic or oestrogenic effects for certain environmental toxins in male reproductive tract abnormalities ${ }^{26}{ }^{27}$ is an added factor which merits further consideration both for the aetiology of milder genital anomalies (that is simple hypospadias) and for the variable expression of mutations in sex determining genes.

This work was supported by the Medical Research Council. Mrs Carole Elford is gratefully acknowledged for excellent technical assistance. 1 Batch J, Patterson M, Hughes I. Androgen insensitivity syn-
drome. Reproductive Medicine Reviews 1992;1:131-50.
2 Pinsky L, Trifiro M, Kaufman M, et al. Androgen resistance due to mutation of the androgen receptor. Clin Invest Med 1994;15:456-72

3 Quigley C, De Bellis A, Marschke K, et al. Androgen receptor defects: historical, clinical, and molecular perspectives. Endocr Rev 1995;16:271-321.

4 Lubahn D, Brown T, Simental J, et al. Sequence of the intron/exon junctions of the coding region of the human androgen receptor gene and identification of a point mutation in a family with complete androgen insensitivity. Proc Natl Acad Sci USA 1989;86:9534-8.

5 Jenster G, van der Korput $\mathrm{H}$, van Vroonhoven $\mathrm{C}$, et al. Domains of the human androgen receptor involved in steroid binding, transcriptional activation, and subcellular oid binding, transcriptional activation, and sub

6 Gottlieb B, Trifiro M, Lumbroso R, et al. The androgen receptor gene mutations database. Nucleic Acids Res 1996;24:151-4.

7 Wilson J, Harrod M, Goldstein J, et al. Familial incomplete male pseudohermaphroditism, type I: evidence for androgen resistance and variable clinical manifestations in a family with Reifenstein syndrome. $N$ Engl f Med 1974;290: 1097-103.

8 Maes $M$, Lee $P$, Jeffs $R$, et al. Phenotypic variation in a family with partial androgen insensitivity syndrome. Am $\mathcal{F} D$ is Child 1980;134:470-3.

9 Batch J, Davies H, Evans B, et al. Phenotypic variation and detection of carrier status in the partial androgen detection of carrier status in the partial androgen
insensitivity syndrome. Arch Dis Child 1993;68:453-7.

10 Evans B, Jones T, Hughes I. Studies of the androgen receptor in dispersed fibroblasts: investigation of patients with androgen insensitivity. Clin Endocrinol (Oxf) 1984;20:93105.

11 Sambrook J, Fritsch E, Maniatis T. Isolation of high molecular weight DNA from mammalian cells. Molecular cloning. Cold Spring Harbor, NY: Cold Spring Harbor Laboratory Press, 1989:9.14-23.

12 Batch J, Williams D, Davies H, et al. Androgen receptor gene mutations identified by SSCP in fourteen subjects with androgen insensitivity. Hum Mol Genet 1992;1:497503.

13 Evans B, Harper M, Daniells C, et al. Low incidence of androgen receptor gene mutations in human prostatic tumors using single strand conformation polymorphism analysis. Prostate 1996;28:162-71.

14 Beitel L, Kazemi-Esfarjani P, Kaufman M, et al. Substitution of arginine- 839 by cysteine or histidine in the androgen receptor causes different phenotypes in culture cells and coordinates different degrees of clinical androgen resistance. F Clin Invest 1994;94:546-54.

15 McPhaul M, Marcelli M, Zoppi S, et al. Mutations in the ligand binding domain of the androgen receptor gene cluster in two regions of the gene. $\mathcal{f}$ Clin Invest 1992;90:2097101 .

16 Marcelli M, Zoppi S, Wilson C, et al. Amino acid substitutions in the hormone-binding domain of the human androgen receptor alter the stability of the hormone receptor complex. F Clin Invest 1994;94:1642-50.

17 Imasaki K, Hasegawa T, Okabe T, et al. Single amino acid substitution (840Arg $\rightarrow$ His) in the hormone-binding domain of the androgen receptor leads to incomplete androgen insensitivity syndrome associated with a thermolabile receptor. Eur f Endocrinol 1994;130:569-74.

18 Hughes I, Patterson M. Prenatal diagnosis of androgen insensitivity. Clin Endocrinol (Oxf) 1994;40:295-6.

19 Wurtz J, Bowget W, Renand J, et al. A canonical structure for the ligand-binding domain of nuclear receptors. Nature (Struct Biol) 1996;3:87-94.

20 Beck Peccoz P, Chatterjee K. The variable clinical phenotype in thyroid hormone resistance syndrome. phenotype in thyroid

21 Schafer A, Dominquez-Steglich M, Guioli S, et al. The role of the SOX9 in autosomal sex reversal and campomelic dysplasia. Phil Trans R Soc London 1995;350:271-8.

22 Evans B, Bowen D, Smith P, et al. A new point mutation in the luteinising hormone receptor gene in familial and sporadic male limited precocious puberty: genotype does not always correlate with phenotype. F Med Genet 1996;33:1437.

23 Themmen A, Brunner H. Luteinizing hormone receptor mutations and sex differentiation. Eur $\mathcal{f}$ Endocrinol 1996;134:533-40.

24 New M. Where phenotype does not match genotype. Frontiers of endocrinology. Vol 16. Rome:Ares-Serono Symposia, tiers of

25 Bevan C, Brown B, Davies H, et al. Functional analysis of six androgen receptor mutations identified in patients with partial androgen

26 Irvine $\mathrm{S}$. Is the human testis still an organ at risk? $B M \mathcal{F}$ 1996;312:1557-8

27 White R, Jobling S, Hoare S, et al. Environmentally persistent alkylphenolic compounds are estrogenic. Endocrinology 1994;135:175-82. 